\title{
Yatırımcıların Finansal Okuryazarlık ve Bilişsel Yetenek Düzeylerinin Psikolojik Yanılsamalar ile İlişkisi*
}

Durmuş SEZER ** Sezgin DEMIR ${ }^{* * *}$

\section{ÖZET}

$\mathrm{Bu}$ çalışmanın amacı, yatırımcıların finansal okuryazarlık ve bilişsel yetenek düzeylerini saptamak ve yatırımcıların finansal okuryazarlık ve bilişsel yetenek düzeyleri ile psikolojik yanılsamalar arasındaki ilişkiyi belirlemektir. Yatırımcılara uygulanan anket çalışmasıyla, yatırımcıların finansal okuryazarlık ve bilişsel yetenek düzeylerindeki değişmelerin psikolojik önyargılar ile olan ilişkisi değerlendirilmiştir. Elde edilen bulgulara göre, ankete dahil edilen yatırımcıların bilişsel yetenek ve finansal okuryazarlık düzeyleri Amerika, Almanya ve Hollanda'daki araştırmalar ile karşılaştırıldığında oldukça düşük düzeydedir. Benzer şekilde bu kapsamdaki yatırımcılar, bilişsel yetenek ve finansal okuryazarlık düzeylerinden bağımsız olarak yoğun bir şekilde psikolojik yanılsamalara maruz kalmaktadır.

Anahtar Kelimeler: Davranışsal Finans, Beklenti Kuramı, Hevristikler, Finansal Okuryazarlık, Bilişsel Yetenekler.

JEL Sınıflandırması: G11, G02.

Investors' Levels of Financial Literacy and Cognitive Ability and Their Relationship with Psychological Illusions

\section{ABSTRACT}

The aim of this research is to determine investors' level of financial literacy and cognitive ability and to designate the relationships among financial literacy, cognitive abilities and psychological illusions. For this purpose, a survey study is conducted for measuring the level of financial literacy and cognitive abilities and their relationship with psychological illusions. According to the findings of the survey, investors' cognitive ability and financial literacy levels are quite low compared to the levels of American, German and the Dutch investors. Similarly, in this context, investors are exposed to intense psychological illusions regardless of their level of cognitive ability and financial literacy.

Keywords: Behavioral Finance, Prospect Theory, Heuristics, Financial Literacy, Cognitive Abilities.

Jel Classification: G11, G02.

\footnotetext{
* Bu çalışma "Yatırımcı Davranışlarının Etkinliği ve Psikolojik Yanılsamalar" isimli doktora tezinden türetilmiştir.

** Yrd. Doç. Dr. Durmuş Sezer, Nazilli İktisadi ve İdari Bilimler Fakültesi, dsezer09@hotmail.com

${ }^{* * *}$ Doç. Dr. Sezgin Demir, Nazilli İktisadi ve İdari Bilimler Fakültesi
} 


\section{GİRIŞ}

İktisadi sistemlerin en temel öğelerinden birisi bireylerin karar alırken sergiledikleri tutumlardır. Finans biliminde de bireyin karar verme davranışı oldukça önemli bir yere sahiptir. Özellikle, risk ve belirsizlik altında karar verme konusunda birbirinden farklı birçok kuramın ortaya çıktı̆̆ görülmektedir. Risk ve belirsizlik altında karar verme davranışlarını inceleyen kuramlar temelde iki ana başlık altında toplanmaktadır. Bunlardan birincisi yatırımcı rasyonelliğini ön plana çıkaran geleneksel finans kuramları, ikincisi ise karar vericilerin birçok önyargının etkisi altında kaldığını ileri süren davranışsal finans kuramlarıdır.

Geleneksel kuramlar, normatif ve belirli varsayımlar altında oluşturulmuştur. Özellikle, Beklenen Değer Kuramı, Etkin Piyasalar Hipotezi, Portföy Teorisi, Sermaye Varlıklarını Fiyatlandırma Modeli ve Arbitraj Teorisi "rasyoneliteyi" veri kabul edip, bu temel üzerine inşa edilmişlerdir. Buna göre, geleneksel kuramlar, bireyin nasıl olduğundan ziyade nasıl olması gerektiğinden yola çıkmaktadır. Buna karşın, davranışçı kuramlar betimleyici olup, bireyin mevcut durumu üzerine şekillenmişlerdir. Diğer bir ifadeyle, davranış̧ı kuramlar, bireyi olduğu gibi kabul edip, var olanı incelerken diğer bilim dallarından, özellikle de psikoloji biliminden, oldukça fazla yararlanmışıı. Geleneksel kuramlara karşı ortaya çıkan davranışsal finans, bireylerin sistematik olarak hata yaptığını ileri sürmektedir.

Davranışsal finansın temelini, Kahneman ve Tversky (1979) tarafından ortaya konan Beklenti Kuramı oluşturur. Beklenti Kuramı, geleneksel finans kuramlarının "rasyonel insan" ve "sınırsız arbitraj" iddialarına karşı olarak ortaya atılmışıtır.

$\mathrm{Bu}$ çalışmada, IMKB'de işlem yapan bireysel yatırımcıların finansal okuryazarlık ve bilişsel yetenek düzeylerinin belirlenmesinin yanında bu faktörlerin yatırımcıların düştükleri psikolojik yanılsamalara olan etkisi belirlenmeye çalışılmışıtır.

\section{TEMEL KAVRAMLAR VE TEORIKK ALTYAPI}

Davranışsal finansın temelini yatırımcıların işlem yaptıkları sırada düştükleri yanılgılar ve bu yanılgıların dayandığı nedenler oluşturmaktadır. Bu nedenle, finans literatüründe yer alan kavramların dışında bir literatür oluşmuştur. Geleneksel finans teorilerine büyük ölçüde karşı çıkan bu yaklaşım için ayrı bir teorik alt yapının oluşturulması kaçınılmazdır. Bu nedenle bu bölümde öncelikle teorinin anlaşılır hale gelmesi kavramsal çerçevenin çizilmesi ile sağlanacak ve ardından teorik alt yapının nasıl oluşturulduğu üzerinde durulacaktır.

\subsection{Temel Kavramlar}

Davranışsal finans ile ilgili literatürün ülkemiz literatürü açısından yeni olması bazı kavramların tanımlanması faydalı olacaktır. 
Bilişsel yetenek, bir görevde başarılı bir performans için, zihinsel olarak bireyin bilgiyi doğru ya da uygun olarak işleme niteliğidir. Temsiliyet veya benzeşiklik, basmakalıplar (klişeler) üzerine kurulmuş yargıdır. Diğer bir anlatımla, bir şeyin olasılığını belirgin bir stereotipi ne kadar karşıladığı ya da temsil ettiğine göre yargılama stratejisidir. Kumarcı yanılgısı ise, bireylerin temsiliyet kısayoluna aşırı ağırlık vermesi sonucu istatistiksel temel oranları reddetmeleri anlamına gelmektedir.

Bireylerin bir olayın gerçekleşme olasılığına ilişkin karar verirken, aynı olaya ilişkin geçmiş tecrübelerinden yararlanması mevcudiyet kısayolunun sonucudur. Diğer bir anlatımla, insan beyni bir problem ile karşılaştığında, bu problemle ilgili bilgileri hatırda kalma dercesine göre geri çağırır. Eğer, ortaya çıkan olaya ilişkin hafızada bir bilgi yer alıyorsa, birey, bu olayın gerçekleşme ihtimaline daha fazla ağırlık vermekte; buna karşın olaya ilişkin hafızasında bilgi yer almıyorsa daha düşük ağırlık vermektedir.

Bireylerin yargı sürecinde, kolayca hatırlanabilir, yakın geçmişte olan, dikkat çeken ve iyi bilinen olaylara aşırı ağırlık vermesi aşinalık yanılsaması olarak tarif edilmektedir. Çıpalama kısayolu ise, gelecekte alınabilecek kararlarda referans noktası olarak kullanılan doğru veya yanlış inanışlardır. Çıpalama kısayolu ile tutuculuk arasında yakın bir ilişki mevcuttur. Tutuculuk, bireylerin olaylara sabitlenmesi (demir atması) anlamına gelmektedir. Kayıptan kaçınma, bireylerin kazançlardaki artışlarından ziyade azalışlara karşı daha duyarlı olma eğiliminde olmalarıdır. Buna göre, aynı tutardaki bir paranın kaybedilmesi durumunda duyulan üzüntü, kazanımından elde edilen hazdan daha fazla olmakta, dolayısıyla bireyler kayıptan kaçınan bir tutum sergilemektedir. Bilişsel çelişki, bireyin sahip olduğu ve birbiri ile ilgili iki bilişin çatışmasını ifade etmektedir. Diğer bir anlatımla, örneğin, kişinin sahip olduğu inançların birbiriyle ve tutumlarıyla uyuşmaması durumudur.

Belirsizlikten kaçınma, kesinlik etkisinin bir sonucu olarak, pozitif anlamda kesin kazançların daha büyük fakat olasılıklı kazançlara tercih edilmesini ifade etmektedir. Zihinsel muhasebe, bireylerin sahip oldukları her bir lirayı, zihinlerinde farklı şekilde gruplama eğiliminde olduğunu iddia eder. Buna göre, bir zihinsel hesaptaki para diğer bir hesaptaki aynı tutardaki paranın yerine geçememektedir. Diğer taraftan, insanlar, daha önce aldığ1 kararlar dolayısıyla acı çekiyorsa bu bir pişmanlığın ifadesi iken mutluluk duyması halinde ise bu bir gururun ifadesine dönüşmektedir. Dolayısıyla, bireylerin davranışlarını pişmanlıktan kaçınma ve övünç arayışı gibi iki güçlü duygu etkilemektedir. Hedonik düzeltme, bireylerin mutluluklarını ençoklamak için, kazançlarını ayrı ayrı değerlendirdiği buna karşın kaybın verdiği hüznü azaltmak için ise toplam kaybı hesaba kattığı varsayımına dayanmaktadır. Son olarak, çerçeveleme, insanların bir karar problemi üzerinde düşünürken sadece bu probleme odaklanıp, mevcut problemi diğer seçeneklerden ayırma eğiliminde olmaları anlamına gelir.

\subsection{Teorik Altyapı}

Geleneksel finansın öncülerinden Milton Friedman (1953), rasyonel olmayan ekonomi ajanlarının rekabet ortamında var olamayacağını ve nihai olarak piyasa dışında kalacağını 
ifade ederek, uzun dönemde rasyonel bireylerin kalıcı olacağını savunmuştur. Buna karşın, Nobel ekonomi ödüllü Herbert A. Simon (1956), alternatifler hakkındaki bilgi ve bilgi işleme yetersizliği gibi engeller nedeniyle tam rasyonellikten bahsedilemeyeceğini fakat bireyler için "sınırlı rasyonellik" (bounded rationality) olabileceğini ileri sürmüştür. Daha açık bir ifadeyle, bireyin kolektif rasyonel seçimini esas alan sınırlı rasyonellik, bireyin hesaplama kapasitesi ile ilgili sınırlarını, yapacağı seçime ilişkin bilgi noksanlıklarını ve çoklu amaçlar arasında karar verme konusundaki sınırlarını kapsamaktadır (Callebaut, 2007: 77).

Yukarıda sayılan sinırlılıklar nedeniyle, bireyler bir karar problemi ile karşılaştıklarında, eğer daha önce gözlemlenen bir durum ile karşılaşırlarsa geçmişteki tecrübelerine göre davranışlarını tekrarlarlar bunun dışında yeni ve beklenmeyen bir durum ile karşılaşırlarsa bu durumda yeni çözüm yolları ararlar. Daha sonra, problem çözme prosedürleri harekete geçer ve bilgiler toplanır. Ancak, gerçek yaşamdaki belirsizliklerden dolayı, gerek alternatifler gerekse de bunların sonuçları tam olarak değerlendirilemeyeceği için, araştırma sürecinin basitleştirilmesi amaciyla hevristikler (kısa yollar) devreye sokulur. $\mathrm{Bu}$ nedenle, karar alıc1, optimal faydadan ziyade "tatmin düzeyi" (aspiration level) olarak adlandırılan düzeyi bulmaya çalışır. Bu düzey, bireyin amacını karşılayan seviyeye denir ve buna göre piyasa katılımcıları, "tatminkar" bireylerdir (Fiori, 2005; Callebaut, 2007; Gigerenzer ve Selten, 2002).

Davranışsal finansın ortaya çıkmasında en önemli katkıyı Beklenti Teorisini oluşturan Tversky ve Kahneman (1979) yapmıştır. Beklenti Teorisi, belirsizlik altında alınan birçok kararın inanış temelli olduğunu ve insanların karmaşık olguları basite indirgemek için birtakım hevristiklere (kısa ve kestirme yollara, sezgilere) güvendiğini belirtmiştir. Buna göre kısayollar, karar vermeyi kolaylaştırırken birtakım yanılsamalara ve yatırım kararları sonuçlarının idealin altında kalmasına yol açabilir (Ritter, 2003: 3).

$\mathrm{Bu}$ kısayolların bazıları; temsiliyet, mevcudiyet (var olma-bulunma) ve çıpalama (demir atma) iken bunların sonucu oluşan yanılsamalardan bazıları ise, aşırı güven, aşırı iyimserlik, tutuculuk, sürü psikolojisi, statüko yanlılığı, ben biliyordum yanılsaması, kumarc1 yanılgıs1 olarak sayılabilir (Tversky ve Kahneman, 1974, Ritter, 2003, Sheffrin, 2007).

Diğer taraftan, bireylerin karar verme sürecini sınırlayabilecek birtakım yanılsamalar da mevcuttur. Zihinsel yanılsamalar olarak da adlandırılabilecek olan bu yanılsamalar kayıptan kaçınma, bilişsel çelişki, pişmanlıktan kaçma, çerçeveleme etkisi, hedonik düzeltme, belirsizlikten kaçınma ve zihinsel muhasebe olarak sayılabilir (Kahneman ve Tversky, 1979, Thaler ve Johnson, 1990, Bernartzi ve Thaler, 1995).

Yatırımcı davranışlarını etkileyen benzer birçok değişkenin olmasına karşın, günümüzde hisse senetlerinin geçmiş fiyat hareketlerine bakarak karar verme oldukça popülerdir (Zielonka, 2004: 218) ve bunun iki nedeni olabilir. Zielonka (2004), bu nedenlerden birincisinin gelenek ve eğitim olabileceğini, yatırımcıların bu analiz yöntemini yüzyılı aşkın bir süredir kullandığını ve piyasaya yeni katılanların da bu yöntemi eski piyasa 
katılımcılarından öğrendiğini ileri sürmektedir. Zielonka'ya göre (2004) ikinci neden ise, insanların davranışlarını etkileyen bazı genel bilişsel önyargılardır.

Kahneman ve Tversky (1979) tarafindan ortaya atılan Beklenti (Umut) Teorisi akıldaki algısal izlerden yola çıkarak insanın sübjektif yargıları ile uyumlu pozitif bir iktisat düşüncesini bağdaştırmaya çalışmaktadır (Abaan, 2002: 213). Diğer taraftan, Kahneman ve Tversky (1979) teorilerinde, insanların açıklanması imkânsız şekilde kararlar aldıklarını savunmaktadır.

Diğer taraftan, günümüzde finansal okuryazarlık dünyadaki gelişmiş ülkelerin oldukça üstünde durduğu bir konudur. Örneğin, Amerika Birleşik Devletleri (ABD)'nde finansal eğitim çalışmaları kapsamında, 2002 yılında "Finansal Eğitim Bürosu" (Office of Financial Education) kurulmuştur. 2003 yılında ise ABD Kongresi "Finansal Okur-Yazarlık ve Eğitimi Komisyonu"nu (Financial Literacy and Education Commission - FLEC) kurmuştur. 2007 yılında Avrupa Birliği'nde (AB) de, finansal eğitim konusunda bir bildiri ile bazı temel prensipler ve gelecekte uygulanması düşünülen planlar açıklanmıştır.

Akademik yazında da, finansal okuryazarlık konusu son dönemde oldukça araştırılan bir konudur. Örneğin, Van Rooij, Lusardi ve Alessie (2011), finansal okuryazarlık ile piyasa katılımı arasındaki ilişkiyi ölçmek için Hollanda hanehalkına yaptıkları çalışmada oldukça çarpıcı sonuçlara ulaşmışlardır. Çalışmadan elde edilen sonuçlara göre, çoğu hanehalkının enflasyon, faiz oranı gibi temel bazı finansal bilgilere sahip olmasına karşın, tahvil ile hisse senedi arasındaki farkı, faiz oranı ile tahvil fiyatları arasındaki ilişkiyi ve risk çeşitlendirmesine ilişkin temel bilgileri bilmediği sonucuna ulaşmıştır.

Guiso ve Japelli (2008), finansal okuryazarlık ile portföy çeşitlendirmesi arasındaki ilişkiyi incelemişlerdir. Buna göre, çalışmada İtalyan yatırımcıların finansal okuryazarlık düzeylerinin düşüklügünün, portföy çeşitlendirmesinin olumsuz etkilenmesine yol açtığ saptanmıştır.

12-17 yaş arası Amerikan öğrencilerinin sadece üçte birinden daha azı faiz oranı, enflasyon ve risk çeşitlendirmesine ilişkin temel bilgilere sahipken (Lusardi, Mitchell ve Curto, 2010), 55 yaş ve üzeri grupta finansal entelektüellik oldukça düşük düzeydedir (Lusardi, Mitchell ve Curto, 2012). Kimball ve Shumway (2006), yatırımcı entelektüelliği ile piyasa katılımı, yerellik yanılsaması, çeşitlendirme ve işveren hisse senedi muamması arasındaki ilişkiyi araştırmıştır. Çalışmadaki bulgulara göre, yatırımcı entelektüelliği artıkça; piyasa katılımı, uluslararası hisselere yatırım, çeşitlendirme artmakta ancak işveren hisselerine olan eğilim azalmaktadır.

$\mathrm{Bu}$ çalışmaların dışında, finansal okuryazarlık düzeyleri düşük olan bireylerin borç problemi ile karşılaşacağı (Lusardi ve Tufano, 2009), servet sahibi olma ve onu yönetme konusunda yetersiz kalacağ 1 (Hogart, Beverly ve Hilgert, 2003), finansal kriz dönemlerinde borç alma ve gelirlerini harcama (Klapper, Lusardi ve Panos, 2012) ve emeklilik planlaması konusunda problem yaşayacağı (Van Rooij, Lusardi ve Alessie, 2011) ifade edilmektedir. 
Bilişsel yetenekler ile portföy tercihlerine ilişkin olarak yaptıkları çalışmada Christelis, Japelli ve Padula (2010), Avrupa'nın 11 ülkesinde (Avusturya, Belçika, Danimarka, Fransa, Almanya, Yunanistan, İtalya, Hollanda, İspanya, İsveç ve İsviçre) 50 yaş üstü bireylerdeki portföy tercihlerinin bilişsel yetenekler ile ilişkili olduğunu bulmuşlardır. Buna göre, bilişsel yetenekler ile hisse senedi bulundurma arasındaki ilişkide bilgi engelleri (eksiklikleri) önemli iken, sağlık durumu hisse sahipliğini olumsuz etkilemekte buna karşın sosyal faaliyetler hisse sahipliği ile pozitif korelasyonludur.

Bilişsel yeteneklerin psikolojik yanılsamaları düşürüp düşürmediğini inceleyen Benjamin ve Shapiro (2005), Harvard Üniversitesi lisans öğrencileri ile Şili’li lise öğrencilerine yönelik iki laboratuar çalışması yapmışlardır. Çalışmanın sonuçlarından birincisi, en yüksek değerde bilişsel yeteneğe sahip olan bireylerin bile önemli derecede yanılsamalar gösterdiğidir.

Frederick ise (2005), bireylerin karar davranışları ile bilişsel yetenekleri arasındaki ilişkiyi incelemiştir. Buna göre, bilişsel yetenek skorları yüksek olan bireylerin daha sakin ve risk almaya daha meyilli olduklarını saptamıştır. Frederick çalışmasında, bilişsel yetenekleri ölçmek için, üç-maddeli Bilişsel Yansıma Testi'ni (BYT) (Cognitive Reflection Test, CRT) kullanmıştır.

Bucher-Koenen ve Ziegelmeyer (2011) ise, Avrupa Merkez Bankası ve Lüksemburg Merkez Bankası'nın ortaklaşa organize ettiği "Hanehalkı Finans ve Tüketimi” konulu konferansta sundukları çalışmada; finansal kriz, finansal okuryazarlık ve BYT arasındaki ilişkiyi Alman hanehalkı üzerinde araştırmışlardır. Çalışmada, Bucher-Koenen ve Ziegelmeyer (2011), bilişsel yetenekleri ve finansal bilgi düzeyleri düşük hanehalkını "hata yapmaya meyilli ve riskli varlıklardan uzak duranlar" olarak nitelendirmişlerdir.

Oechssler, Roider, ve Schmitz (2008) ise, çoğu üniversite öğrencisi olan 125 katılımcıya BYT ile bazı önyargılara ilişkin olarak internet üzerinden uygulama yapmıştır. Ancak, Frederick'ten farklı olarak, bilişsel yetenek gruplarını ikiye ayırmıştır. Buna göre, düşük düzey grubunu tüm sorulara yanlış cevap veren katılımcılar ile sadece bir soruya doğru cevap veren katılımcılar oluştururken; yüksek düzey grubunu iki veya daha fazla soruya doğru cevap veren katılımcılar oluşturmaktadır.

Son olarak, Cascio ve Lewis (2005), eğitimin bilişsel yeteneği yükselteceğini ifade etmektedir. Cascio ve Lewis (2005) yaptıkları çalışmada, eğitim ile yetenek eksikliğinin \%25 ile $\% 50$ arasında giderilebileceğini iddia etmektedirler.

\section{UYGULAMA}

Bu çalışmanın temel amacı; Türkiye'deki yatırımcıların finansal okuryazarlık ve bilişsel yetenek düzeylerini saptamak ve yatırımcıların finansal okuryazarlık ve bilişsel yetenek düzeyleri ile psikolojik önyargılar arasındaki ilişkiyi belirlemektir. 
Çalışmanın verileri yatırım yapan kişilere uygulanan anketlerden elde edilmiştir. $\mathrm{Bu}$ nedenle hiç yatırım yapmayan kişilere oranla katılımcıların finansal okuryazarlık ve bilişsel yetenek düzeylerinin belirli bir düzeyde olduğu, önyargılar konusunda bilinçli oldukları ve bu yatırımcılardan toplanacak verilerin analizi sonucu elde edilecek bulguların Türkiye genelindeki yatırımcıları temsil edebilir olduğu varsayılmaktadır.

Bu çalışmada, araştırma türlerinden betimleyici araştırma ve araştırma modeli olarak da survey ve arşiv modeli (tasarımı) kullanılmıştır. Finansal okuryazarlık, bilişsel yetenek ve yanılsamalar arasındaki ilişkiyi belirlemeye yönelik bir çalışma olduğu için, birlikte değişme ilişsisi üzerinde durulmuştur.

\subsection{Yöntem}

Araştırmada veri toplama yöntemi olarak, hazır veriden yararlanma ve yazılı soru sorma (anket) yöntemleri kullanılmıştır. Yatırımcıların finansal okuryazarlık ve bilişsel yetenek düzeyleri ile yanılsamaların belirlenmesi amacı ile de anket uygulanmıştır.

Anket formu dört alt başlıktan oluşmaktadır. İlk alt başlıkta, cevaplayacakların cinsiyet, yaş, eğitim seviyesi gibi demografik özelliklerine ilişkin sorular ile katılımcının yatırım yaptığı yatırım araçları, kullandıkları bilgi kaynakları ve bu bilgi kaynaklarını hangi sıklıkta kullandıklarına ilişkin sorular bulunmaktadır. İkinci altbaşlıkta, cevaplayıcılara 10 adet soru sorularak, yatırımcıların düştükleri bazı yanılsamalar belirlenmeye çalışılmıştır. $\mathrm{Bu}$ bölümdeki sorular, çeşitli kaynaklardan derlenmiştir.

Üçüncü altbaşlıkta ise, finansal okuryazarlık düzeyinin belirlenmesine ilişkin sorular yer almaktadır. Bu sorular, van Rooij, Lusardi ve Alessei (2011) tarafından geliştirilen hanehalkı finansal bilgi düzeyleri ile piyasaya katılımı arasındaki ilişkinin belirlenmesi için yapmış olduğu çalışmadan uyarlanmıştır. Van Rooij vd. (2011), finansal okuryazarlığın belirlenmesi için iki modül geliştirmiştir. Bunlardan birincisi temel finansal bilgi düzeyini tahmin etmek için tasarlanmıştır. Burada faiz oranı, enflasyon etkisi, iskonto ile reel ve nominal değerlere ilişkin sorular bulunmaktadır. İkinci soru seti, ileri finansal bilgi düzeyini ölçmeyi hedeflemektedir. Burada hisse senedi ile tahvil arasındaki farklar, menkul kıymetler piyasasının fonksiyonları, risk çeşitlendirme ve tahvil fiyatları ile faiz oranları arasındaki ilişkiye ilişkin sorular bulunmaktadır. Birinci modülde yer alan sorular, temel finansal okuryazarlık düzeyini ikinci modülde yer alan sorular ise, ileri düzey okuryazarlığı düzeyini ölçmeye yönelik olarak tasarlanmıştır. Dolayısıyla, iki ayrı finansal okuryazarlık indeksi oluşturulmuştur. Çalışmada, finansal okuryazarlık düzeyleri, yüzdelik olarak dört kartile ayrılmıştır. Bu kartillerden düşük düzeyde olanlar, birinci kartilde (\%25), yüksek düzeyde olanlar dördüncü kartilde (\%25) yer almaktadır.

İndeksin geçerliliğinin onaylanması için, bu indekslerin eğitim, yaş ve cinsiyet arasındaki dağılımı analiz edilmiştir. Yapılan analiz sonucu, temel finansal okuryazarlık indeksinin eğitim ile birlikte önemli artış gösterdiği ve kadınların erkeklere göre daha düşük 
temel finansal okuryazarlık düzeyine sahip olduğu saptanmıştır. Bunun yanında, ileri düzey finansal okuryazarlık indeksinin de eğitim ile önemli bir artış gösterdiği saptanmıştır.

$\mathrm{Bu}$ çalışmada, temel finansal okuryazarlık seviyelerini belirlemek için ilk soru setinde beş adet soru bulunmaktadır. Burada yatırımcılar; finansal okuryazarlık bakımından, düşük ve yüksek düzey olarak iki gruba ayrılmıştır. Düşük düzey, hiçbir soruya doğru cevap veremeyen yatırımcılar ile herhangi bir veya iki soruya doğru cevap veren yatırımcılardan; yüksek düzey ise, herhangi üç ve üzeri soruya doğru cevap veren yatırımcılardan oluşmaktadır.

Diğer taraftan, ileri düzey finansal okuryazarlık seviyesini belirlemek için ikinci soru setinde onbir adet soru bulunmaktadır. Burada da yatırımcılar; düşük ve yüksek düzey olarak ayrılmıştır. Düşük düzey, hiçbir soruya doğru cevap veremeyen yatırımcılar ile herhangi beş soruya doğru cevap veren yatırımcılardan; yüksek düzey ise, herhangi altı veya üzeri sorulara doğru cevap veren yatırımcılardan oluşmaktadır.

Anket formunun son altbaşlığında Frederick'in (2005) bilişsel yetenekleri ölçmek için kullandığı üç-maddeli Bilişsel Yansıma Testi kullanmıştır. BYT, 35 ayrı çalışmada 2003 yılından başlayarak 26 aylık sürede 3,428 kişiye uygulanmıştır. Çoğu katılımcı, ABD’nin ortabatı ve kuzeydoğusundaki çeşitli üniversitelerde lisans eğitimi gören öğrencilerden oluşmaktadır. Katılımcılardan, BYT ve değişik karar verme karakteristiklerinin (örneğin zaman ve risk tercihleri) de bulunduğu 45 dakikalık anketi tamamlamaları istenmiştir. Frederick yaptığı analizde, düşük grup (3 sorunun tamamını yanlış cevaplayanlar) ile yüksek grup (3 sorunun tamamını doğru cevaplayanlar) arasında karşılaştırma yapmıştır.

$\mathrm{Bu}$ çalışmada, Frederick'in çalışmasından farklı olarak yatırımcılar iki gruba ayrılmıştır. Burada Oechssler, Roider, ve Schmitz'in (2008), çalışması örnek alınarak yatırımcılar bilişsel yetenek yönünden düşük ve yüksek düzey olmak üzere iki düzeyde temsil edilmektedir. Düşük düzey, hiçbir soruya doğru cevap veremeyen yatırımcılar ile herhangi bir soruya doğru cevap veren yatırımcılardan; yüksek düzey ise, herhangi iki soruya veya soruların tamamına doğru cevap veren yatırımcılardan oluşmaktadır.

Anket kapsamında yukarıda ifade edilen sorular arasında, 5'li Likert Ölçekli katılım soruları, çoktan seçmeli sorular ve üç adet açık uçlu soru yer almaktadır.

\subsection{Veri}

Çalışmada, Türkiye Sermaye Piyasası Aracı Kuruluşlar Birliği (TSPAKB) tarafından 2013 yılı yatırımcı analizine ilişkin Merkezi Kayıt Kuruluşu (MKK) verileri kullanılmıştır. MKK verilerine göre, Türkiye'de 31 Aralık 2013 tarihi itibariyle yaklaşı bir milyonun üzerinde (1.090.000) hisse senedi yatırımcısı bulunmaktadır. Toplam yatırımcıların yaklaşık \%99.3'ü gerçek kişi, \%0.7'si tüzel kişi (banka, aracı kurum, holding vb.) veya diğer (vakıf, kooperatif vb.) olarak sınıflandırılan yatırımcılarından oluşmaktadır.

$\mathrm{Bu}$ çalışmada, İMKB'de hisse senedine yatırım yapan gerçek kişi yatırımcılar incelenecektir. İMKB'deki toplam hisse senedi portföyünün yaklaşık 30 milyar TL'lik kısmı 
gerçek kişilere aittir. Gerçek kişilerin sahip olduğu bu portföyün yaklaşık \%98,6'sına ise yerli yatırımcılar sahiptir. Çalışmanın evrenini İstanbul, Ankara ve İzmir'de İMKB'de hisse senedi alıp satan gerçek kişi yatırımcılar oluşturmaktadır. Çalışma evreninin üç büyük şehir seçilmesinin nedeni, bu şehirlerdeki bireysel yatırımcılara erişimin çok daha kolay olmasıdır.

Yaklaşık bir milyon olan toplam yatırımcıların, yaklaşık 580.000'i adı geçen illerde yaşamaktadırlar. 580.000 kişinin yaklaşık \%60’1 İstanbul, \%22'si Ankara ve \%18'i ise İzmir'dedir. Araştırmanın örneklemi, $n=\frac{N t^{2} p \cdot q}{d^{2}(N-1)+t^{2} p \cdot q}$ formülü kullanılarak, \%95 güven aralığında \%5 hata payını kabul edildiğinde, örneklem sayısı 384 kişi olarak hesaplanmıştır.

Verilerin analizi için SPSS (Statistical Package for Social Sciences) paket programı kullanılmıştır. Çalışmada elde edilen verilerin ordinal olması ve değişkenlerin dağılımının normal dağılıma uymaması nedeniyle analizde parametrik olmayan ilişkileri analiz etmeye izin veren Spearman sıra korelasyonu kullanılmıştır.

Çalışmadaki anket sorularının ölçek güvenilirliği, Cronbach alfa katsayısı ile kontrol edilmiştir. Cronbach alfa katsayılarının 0,50 değerinden büyük çıkması ölçek güvenilirliğinin sağlandığını göstermektedir (Nunnaly, 1978). Yapılan analiz sonucu, ölçeklere ait Cronbach alfa değerlerinin 0,645 çıktığı görülmüsştür. Cronbach alfa değerleri belirlenirken, demografik değişkenler ve bilişsel yeteneklere ilişkin 3 soru açık uçlu olduğu için dışarıda bırakılmıştır, bu nedenle 53 değişken üzerinden güvenirlik analizi yapılmıştır.

\subsection{Bulgular}

Çalışmanın bu bölümünde, psikolojik önyargılar, finansal okuryazarlık, bilişsel yetenekler ve risk tercihleri arasındaki ilişkinin yönü ve şiddetini görmek için bu değişkenler üzerinde korelasyon analizi uygulanmıştır. Elde edilen veriler, parametrik olmayan veriler olması nedeniyle, çalışmada Spearman korelasyonu kullanılmıştır.

\subsubsection{Bilişsel Yetenek Düzeyleri ve Yanılsamalar Arasındaki İlişki}

Çalışmanın bu kısmında, yatırımcıların bilişsel yetenek düzeyleri ile psikolojik önyargılar arasındaki ilişki araştırılmıştır. Bu ilişkiye ilişkin hipotez aşağıdaki gibidir.

$H_{0}$ : Yatırımcıların bilişsel yetenek düzeyi ile psikolojik önyargılar arasında ilişki yoktur.

$\mathrm{H}_{1}$ : Yatırımcıların bilişsel yetenek düzeyi ile psikolojik önyargılar arasında ilişki vardir.

Korelasyon analizinden elde edilen bulgulara göre, bilişsel yetenek düzeyleri ile çıpalama kısayolu, tutuculuk yanılsaması, kumarbaz yanılgısı, aşinalık yanılsaması ve yatkınlık etkisi arasında p değeri 0.05 'ten büyük olduğu için istatistiksel olarak anlamlı bir ilişki bulunamamıştır. Dolayısıyla, adı geçen önyargılar için, yatırımcıların bilişsel yetenek düzeyi ile önyargılar arasında ilişki yoktur $\left(\mathrm{H}_{0}\right)$ hipotezi kabul edilmektedir. 
Buna karşın, bilişsel yetenekler ile aşırı tepki, yerellik yanılsaması ve mevcudiyet kısayolu arasında anlamlı sonuçlara ulaşılmıştır. Korelasyon analizinden elde edilen bulgulara göre, bilişsel yetenek düzeyleri ile aşırı tepki, yerellik yanılsaması ve mevcudiyet kısayolu arasında istatistiksel olarak $\mathrm{p}=0.01$ düzeyinde anlamlı bir ilişki bulunmuştur. Aşağıdaki tablolarda, bu yanılsamalara ilişkin dağılımlar verilmiştir.

Tablo 1. Bilişsel Yetenekler ve Aşırı Tepki Yanılsaması

\begin{tabular}{|l|c|c|c|c|}
\hline \multirow{2}{*}{$\begin{array}{c}\text { Aşırı Tepki (İhraç } \\
\text { Haberi) }\end{array}$} & \multicolumn{3}{|c|}{ Bilişsel Yetenekler (\%) } \\
\cline { 2 - 4 } & Yüksek Düzey & Düşük Düzey & Korelasyon Katsayısı & P \\
\hline Dikkate Almam & 56,2 & 38,5 & \multirow{2}{*}{, 158} & \multirow{2}{*}{002} \\
\hline Alım Yaparım & 43,8 & 61,5 & \\
\hline
\end{tabular}

Tablo 1'deki verilere bakıldığında, bilişsel yetenekler ile aşırı tepki arasında zayıf da olsa bir ilişki vardır ve bu ilişki pozitif yönlüdür. Diğer bir ifadeyle, yüksek bilişsel yetenek düzeyinde, yeni hisse senedi ihraç haberini dikkate almam diyen yatırımcıların oranı artarken, düşük bilişsel yetenek düzeyinde alım yaparım diyenlerin oranı artmaktadır. Aşırı tepki, bir firmaya ilişkin arka arkaya birkaç olumlu haberin ortaya çıkmasıyla yatırımcıların o firmanın hisse senetlerine aşırı ilgi göstermesini ifade etmektedir. Tablo 1'de de görüleceği üzere, yüksek düzeyde bilişsel yeteneğe sahip yatırımcılar, aşırı tepki yanılgısına bilişsel yeteneği daha düşük olanlara göre daha az düşmektedir. Dolayısıyla, aşırı tepki yanılgısı için, yatırımcıların bilişsel yetenek düzeyi ile önyargılar arasında ilişki vardır $\left(\mathrm{H}_{1}\right)$ hipotezi kabul edilmektedir. Bilişsel yeteneği yüksek olan yatırımcılar bilişsel yeteneği düşük olan yatırımcılara göre ihraç haberine daha düşük oranda tepki vermektedir. Oysa düşük bilişsel yetenek düzeyinde olan yatırımcılar, daha yüksek oranda alım yapma veya aşırı tepki gösterme eğilimindedirler.

Bilişsel yetenekler ile yerellik yanılsaması arasında da farklılığın olduğu bulgulanmış ve tablo 2'de bu ilişki dağılım tablosu vasıtasıyla gösterilmiştir.

Tablo 2. Bilişsel Yetenekler ve Yerellik Yanılsaması

\begin{tabular}{|l|c|c|c|c|}
\hline \multirow{2}{*}{$\begin{array}{c}\text { Yerellik } \\
\text { Yanılsaması }\end{array}$} & \multicolumn{3}{|c|}{ Bilişsel Yetenekler (\%) } & P \\
\cline { 2 - 3 } & Yüksek Düzey & Düşük Düzey & Korelasyon Katsayıs1 & \\
\hline Hiç & 21,1 & 78,9 & & \multirow{2}{*}{, 000} \\
\hline Nadiren & 37,5 & 62,5 & & \\
\hline Bazen & 31,4 & 68,6 & & \\
\hline Siklıkla & 17,1 & 82,9 & & \\
\hline Daima & 7,1 & 92,9 & & \\
\hline
\end{tabular}

Tablo 2'deki verilere bakıldığında, bilişsel yetenekler ile yerellik yanılsaması arasında zayıf da olsa bir ilişki vardır ve bu ilişki pozitif yönlüdür. Başka bir anlatımla, yüksek bilişsel yetenek düzeyindeki yatırımcılarda yerellik yanılsamasına düşme oranı azalmaktadır. Buna karşın, bilişsel yeteneği düşük olan yatırımcılar, yatırım yaparken sıklıkla ve daima 
bölgemdeki firmaları tercih ederim seçeneğini yüksek oranlarda tercih etmişlerdir. Dolayısıyla, yerellik yanılsaması için yatırımcıların bilişsel yetenek düzeyi ile önyargılar arasında ilişki vardır $\left(\mathrm{H}_{1}\right)$ hipotezi kabul edilmektedir. Bilişsel yeteneği yüksek olan yatırımcılar bilişsel yeteneği düşük olan yatırımcılara göre yerellik yanılsamasına çok daha düşük oranda düşmektedir. Buna karşın, düşük bilişsel yetenek düzeyinde olan yatırımcılar, daha yüksek oranda bildiği ve bölgesindeki firmaların hisse senetlerine yatırım yapma eğilimindedirler.

Bunun yanında, korelasyon analizinin bir diğer sonucu, bilişsel yetenekler ile mevcudiyet kısayolu arasındaki ilişkidir. Tablo 3'te korelasyon analizinden elde edilen sonuca göre bilişsel yetenek düzeyleri ile mevcudiyet kısayolu arasındaki ilişki ortaya konmuştur.

Tablo 3. Bilişsel Yetenekler ve Mevcudiyet Kısayolu

\begin{tabular}{|l|c|c|c|c|}
\hline \multirow{2}{*}{$\begin{array}{c}\text { Mevcudiyet } \\
\text { Kisayolu }\end{array}$} & \multicolumn{3}{|c|}{ Bilişsel Yetenekler (\%) } \\
\cline { 2 - 3 } & Yüksek Düzey & Düşük Düzey & Korelasyon Katsayıs1 & P \\
\hline Hiç & 16,9 & 83,3 & & \multirow{2}{*}{, 004} \\
\hline Nadiren & 29,2 & 70,8 & & \\
\hline Bazen & 38,4 & 61,6 & & \\
\hline Sıklıkla & 25,5 & 74,5 & & \\
\hline Daima & 12,1 & 87,9 & & \\
\hline
\end{tabular}

Tablo 3'deki verilere bakıldığında, bilişsel yetenekler ile mevcudiyet kısayolu arasında zayıf da olsa bir ilişki vardır ve bu ilişki pozitif yönlüdür. Diğer bir anlatımla, yüksek bilişsel yetenek düzeyinde olanlar yatırım yaparken hisse senedi açılış fiyatı ve güncel piyasa faaliyetlerini çok fazla dikkate almazken, düşük bilişsel yetenekte olan yatırımcılar yatırım yaparken mevcudiyet kısayoluna çok fazla başvurmaktadır. Dolayısıyla, mevcudiyet kısayolu için $\mathrm{H}_{1}$ hipotezi kabul edilmektedir. Bilişsel yeteneği yüksek olan yatırımcılar bilişsel yeteneği düşük olan yatırımcılara göre mevcudiyet kısayoluna daha yüksek oranda başvurmaktadır. Buna karşın, düşük bilişsel yetenek düzeyinde olan yatırımcılar, çok daha yüksek oranda açılış fiyatı ve güncel piyasa faaliyetlerine önem verme eğilimindedirler.

Özetle, bilişsel yetenekler ile önyargılar arasındaki ilişkilere bakıldığında, psikolojik önyargıların, bilişsel yeteneklerden bağımsız olarak, yatırım kararlarında çok yaygın olarak kullanıldığı ve bu durumun, davranışsal finansın öngörülerini destekler nitelikte olduğu söylenebilir. Ancak, istatistiksel olarak, bilişsel yetenekler ile çalışmada kullanılan sadece üç tane önyargı arasında anlamlı sonuçlara ulaşılabilmiştir.

\subsubsection{Temel Finansal Okuryazarlık ve Yanılsamalar Arasındaki İlişki}

Çalışmanın bu kısmında, yatırımcıların temel finansal okuryazarlık düzeyleri ile psikolojik önyargılar arasındaki ilişki araştırılmıştır. Bu ilişkiye ilişkin hipotez aşağıdaki gibidir.

$H_{0}:$ Yatırımcıların temel finansal okuryazarlı düzeyi ile psikolojik önyargılar arasında ilişski yoktur. 


\section{$H_{1}$ : Yatırımcıların temel finansal okuryazarlık düzeyi ile psikolojik önyargılar arasında ilişki vardır.}

Korelasyon analizinden elde edilen bulgulara göre, temel finansal okuryazarlık düzeyleri ile çıpalama kısayolu, tutuculuk yanılsaması, aşırı tepki (birleşme haberi), kumarbaz yanılgısı, aşinalık yanılsaması, yerellik yanılsaması, mevcudiyet kısayolu ve yatkınlık etkisine ilişkin istatistiksel olarak anlamlı bir ilişki bulunamamıştır. Bu durum, hem düşük hem de yüksek temel düzey finansal okuryazarlık seviyesinde yer alan yatırımcıların, yatırım kararı alırken benzer şekilde davrandığını ifade etmektedir. Dolayısıyla, yatırımcıların temel finansal okuryazarlık düzeyleri ile çıpalama kısayolu, eksik tepki, aşırı tepki, kumarbaz yanılgısı, aşinalık yanılgısı, mevcudiyet kısayolu ve yatkınlık etkisi arasında ilişki yoktur $\left(\mathrm{H}_{0}\right)$ hipotezi kabul edilmektedir.

Buna karşın, temel finansal okuryazarlık düzeyleri ile yatırım yapılan firmaya ilişkin yeni hisse senedi ihraç haberleri nedeniyle oluşabilecek aşırı tepki ve yerellik yanılsaması arasında istatistiksel olarak anlamlı sonuca ulaşılmıştır. Yapılan korelasyon analizinden elde edilen bulgulara göre, temel finansal okuryazarlık düzeyleri ile aşırı tepki ve yerellik yanılsaması için p değeri 0.05 düzeyinde istatistiksel olarak anlamlı bir ilişki bulunmuştur. Aşırı tepki (ihraç haberi) ile ilgili istatistiki dağılımlar, Tablo 4 ’te verilmiştir.

Tablo 4. Temel Finansal Okuryazarlık ve Aşırı Tepki

\begin{tabular}{|l|c|c|c|c|}
\hline \multirow{2}{*}{$\begin{array}{c}\text { Aşırı Tepki (İhraç } \\
\text { Haberi) }\end{array}$} & \multicolumn{4}{|c|}{ Temel Finansal Okuryazarlık (\%) } \\
\cline { 2 - 3 } & Yüksek Düzey & Düşük Düzey & Korelasyon Katsayıs1 & P \\
\hline Dikkate Almam & 52,9 & 36,9 &,- 100 & \multirow{2}{*}{047} \\
\hline Alım Yaparım & 47,1 & 63,1 & \\
\hline
\end{tabular}

Tablo 4'deki verilere bakıldığında, temel finansal okuryazarlık ile ihraç haberi nedeniyle ortaya çıkabilecek aşırı tepki önyargısı arasında zayıf da olsa bir ilişki vardır ve bu ilişki negatif yönlüdür. Dolayısıyla, ihraç haberleri nedeniyle oluşan aşırı tepki yanılgısı için yatırımcıların temel finansal okuryazarlıkları ile psikolojik önyargılar arasında ilişki yoktur $\left(\mathrm{H}_{0}\right)$ hipotezi reddedilirken, yatırımcıların temel finansal okuryazarlıkları ile psikolojik önyargılar arasında ilişki vardır $\left(\mathrm{H}_{1}\right)$ hipotezi kabul edilmektedir. Temel finansal okuryazarlık düzeyleri yüksek olan yatırımcılar, temel finansal okuryazarlık düzeyi düşük olan bireylere göre ihraç haberleri ortaya çıktığında daha düşük oranda "alım yaparım” seçeneğini tercih etmektedirler. Buna karşın, temel finansal okuryazarlık yönünden düşük düzeyde yer alan yatırımcıların yaklaşık \%63'ü böyle haberlerin ortaya çıkması durumunda "alım yaparım" seçeneğini tercih etmektedirler.

Öte yandan, temel finansal okuryazarlık düzeyleri ile yerellik yanılsaması arasında da ilişkinin olduğu bulgulanmış ve tablo 5 'te bu ilişki gösterilmiştir. 
Tablo 5. Temel Finansal Okuryazarlık ve Yerellik Yanılsaması

\begin{tabular}{|l|c|c|c|c|}
\hline \multirow{2}{*}{ Yerellik Yanılsaması } & \multicolumn{3}{|c|}{ Temel Finansal Okuryazarlık(\%) } \\
\cline { 2 - 3 } & Yüksek Düzey & Düşük Düzey & Korelasyon Katsayısı & P \\
\hline Hiç & 36,8 & 63,2 & & \\
\hline Nadiren & 20,5 & 79,5 & \multirow{2}{*}{-002} \\
\hline Bazen & 42,5 & 57,5 & & \\
\hline S1klıkla & 42,9 & 57,1 & & \\
\hline Daima & 50,0 & 50,0 & & \\
\hline
\end{tabular}

Tablo 5'deki verilere bakıldığında, bilişsel yetenekler ile yerellik yanılsaması arasında zayıf da olsa bir ilişki vardır ve bu ilişki negatif yönlüdür. Diğer bir deyişle, temel finansal okuryazarlık yönünden yüksek düzeyde yer alan yatırımcılarda yerellik yanılsamasına düşme oranı azalmaktadır. Buna karşın, temel finansal okuryazarlık düzeyi düşük olan yatırımcılar, yatırım yaparken yerellik yanılsamasına yüksek oranlarda düşmektedir. Dolayısıyla, yerellik yanılsaması için, yatırımcıların temel finansal okuryazarlık düzeyi ile önyargılar arasında ilişki vardır $\left(\mathrm{H}_{1}\right)$ hipotezi kabul edilmektedir.

Sonuç olarak, psikolojik yanılsamalar, finansal piyasada alım satım yapan yatırımcılar arasında sıkça başvurulan kısayol ve düşülen yanılgılar olmaktadır. Burada yatırımıının temel finansal bilgi düzeyinin ne olduğu önem taşımamakta ve psikolojik yanılgılara düşme, finansal okuryazarlık düzeylerinden bağımsız olmaktadır.

\subsection{3. İleri Düzey Finansal Okuryazarlık ve Yanılsamalar Arasındaki İlişki}

Çalışmanın bu bölümünde, yatırımcıların ileri düzey finansal okuryazarlık seviyeleri ile psikolojik önyargılar arasındaki ilişki araştırılmıştır. Bu ilişkiye ilişkin hipotez aşağıdaki gibidir.

$H_{0}$ : Yatırımcıların ileri düzey finansal okuryazarlık sevileri ile psikolojik önyargılar arasında ilişki yoktur.

$H_{1}$ : Yatırımcıların ileri düzey finansal okuryazarlık seviyeleri ile psikolojik önyargılar arasında ilişki vardır.

Korelasyon analizinden elde edilen bulgulara göre, ileri düzey finansal okuryazarlık seviyeleri ile tutuculuk yanılsaması, aşırı tepki, kumarbaz yanılgısı, aşinalık yanılsaması, yerellik yanılsaması, mevcudiyet kısayolu ve yatkınlık etkisine ilişkin istatistiksel olarak anlamlı bir ilişki bulunamamıştır. Dolayısıyla, yatırımcıların ileri düzey finansal okuryazarlık düzeyleri ile sözü edilen yanılsamalar arasında ilişki yoktur $\left(\mathrm{H}_{0}\right)$ hipotezi kabul edilmektedir.

Bununla birlikte, ileri düzey finansal okuryazarlık seviyeleri ile çıpalama kısayolu arasında p değeri 0.05 'ten küçük olduğu için istatistiksel olarak anlamlı sonuca ulaşılmıştır. Aşağıda çıpalama kısayolu ile ileri düzey finansal okuryazarlık seviyeleri ile ilgili istatistiki dağılımlar Tablo 6'da verilmiştir. 
Tablo 6. İleri Düzey Finansal Okuryazarlık ve Çıpalama Kısayolu

\begin{tabular}{|l|c|c|c|c|}
\hline \multirow{2}{*}{ Çıpalama Kısayolu } & \multicolumn{3}{|c|}{ İleri Düzey Finansal Okuryazarlık (\%) } \\
\cline { 2 - 3 } & Yüksek Düzey & Düşük Düzey & Korelasyon Katsayısı & P \\
\hline Hiç & 30,0 & 70,0 & & \\
\hline Nadiren & 33,3 & 66,7 & & \multirow{2}{*}{, 125} \\
\hline Bazen & 47,4 & 52,6 & \\
\hline Siklıkla & 48,9 & 51,1 & \\
\hline Daima & 60,0 & 40,0 & & \\
\hline
\end{tabular}

Yukarıdaki tabloda, ileri düzey finansal okuryazarlık ile çıpalama kısayolu arasında zayıf da olsa bir iliş̧ki vardır ve bu ilişki pozitif yönlüdür. Bu durumun nedeni, ileri düzey finansal okuryazarlık yönünden yüksek grupta yer alan yatırımcıların çıpalama kısayoluna genel olarak düşük grupta yer alan yatırımcılara göre daha az katılıyor olmalarıdır. Sonuç itibariyle, çıalama kısayolu için, yatırımcıların ileri düzey finansal okuryazarlık seviyeleri ile psikolojik önyargılar arasında ilişki yoktur $\left(\mathrm{H}_{0}\right)$ hipotezi reddedilirken, yatırımcıların ileri düzey finansal okuryazarlık seviyeleri ile psikolojik önyargılar arasında ilişki vardır $\left(\mathrm{H}_{1}\right)$ hipotezi kabul edilmektedir.

\subsubsection{Temel Finansal Okuryazarlık ile Bilişsel Yetenekler Arasındaki İlişki}

$\mathrm{Bu}$ kısımda, temel finansal okuryazarlık düzeyleri ile bilişsel yetenek düzeyleri arasındaki ilişki araştırılmıştır. Bu ilişkiye ilişkin hipotez aşağıdaki gibidir.

$H_{0}$ : Yatırımcıların temel finansal okuryazarlık düzeyleri ile bilişsel yetenek düzeyleri arasında ilişki yoktur.

\section{$\mathrm{H}_{1}$ : Yatırımcıların temel finansal okuryazarlık düzeyleri ile bilişsel yetenek düzeyleri} arasında ilişki vardır.

Yatırımcıların temel finansal okuryazarlık düzeyleri ile bilişsel yetenek düzeyleri arasında $\mathrm{p}$ değeri 0.05 'ten küçük olduğu için istatistiksel olarak anlamlı sonuca ulaşılmıştır. Korelasyon analizinden elde edilen bulgular sonucu, temel finansal okuryazarlık düzeyleri ile bilişsel yetenek düzeyleri ile ilgili istatistiki dağıllımlar tablo 7'de verilmiştir.

Tablo 7. Temel Finansal Okuryazarlık ve Bilişsel Yetenekler

\begin{tabular}{|l|c|c|c|c|}
\hline Temel Finansal & \multicolumn{4}{|c|}{ Bilişsel Yetenekler (\%) } \\
\cline { 2 - 4 } Okuryazarlık & Yüksek Düzey & Düşük Düzey & Korelasyon Katsayıs1 & P \\
\hline Yüksek Düzey & 79,0 & 55,9 & \multirow{2}{*}{, 211} &, 000 \\
\hline Düşük Düzey & 21,0 & 41,1 & \\
\hline
\end{tabular}

Tablo 7'de, temel finansal okuryazarlık düzeyleri ile bilişsel yetenek düzeyleri arasında zayıf da olsa bir ilişki vardır ve bu ilişki negatif yönlüdür. Bu durumun nedeni, yüksek bilişsel yetenek düzeylerindeki yatırımcıların \%79'u aynı zamanda temel finansal okuryazarlık yönünden de yüksek düzey grubunda yer alırken, düşük bilişsel yetenek düzeylerindeki yatırımcıların $\% 55,9$ ’u temel finansal okuryazarlık yönünden yüksek düzey grubunda yer almaktadır. Buna karşın, yüksek bilişsel yetenek düzeylerindeki yatırımcıların 
sadece \%21'i temel finansal okuryazarlık yönünden düşük düzey grubunda yer alırken, düşük bilişsel yetenek düzeylerindeki yatırımcıların $\% 41,1$ 'i temel finansal okuryazarlık yönünden düşük düzey grubunda yer almaktadır. Dolayısıyla, yatırımcıların temel finansal okuryazarlık düzeyleri ile bilişsel yetenek düzeyleri arasında ilişki vardır $\left(\mathrm{H}_{1}\right)$ hipotezi kabul edilmektedir.

\subsection{5. İleri Düzey Finansal Okuryazarlık ile Bilişsel Yetenekler Arasındaki İlişki}

$\mathrm{Bu}$ kısımda, ileri düzey finansal okuryazarlık seviyeleri ile bilişsel yetenek düzeyleri arasındaki ilişski araştırılmıştır. Bu ilişkiye ilişkin hipotez aşağıdaki gibidir.

$H_{0}$ : Yatırımcıların ileri düzey finansal okuryazarlı seviyeleri ile bilişsel yetenek düzeyleri arasında ilişki yoktur.

$\mathrm{H}_{1}$ : Yatırımcıların ileri düzey finansal okuryazarlık seviyeleri ile bilişsel yetenek düzeyleri arasında ilişki vardır.

Yatırımcıların ileri düzey finansal okuryazarlık seviyeleri ile bilişsel yetenek düzeyleri arasında p değeri 0.05 'ten küçük olduğu için istatistiksel olarak anlamlı sonuca ulaşılmıştır. Korelasyon analizinden elde edilen bulgular sonucu, ileri düzey finansal okuryazarlık seviyeleri ile bilişsel yetenek düzeyleri ile ilgili istatistiki dağılımlar tablo 8'de verilmiştir.

Tablo 8. İleri Düzey Finansal Okuryazarlık ve Bilişsel Yetenekler

\begin{tabular}{|l|c|c|c|c|}
\hline İleri Düzey Finansal & \multicolumn{3}{|c|}{ Bilişsel Yetenekler (\%) } \\
\cline { 2 - 4 } Okuryazarlık & Yüksek Düzey & Düşük Düzey & Korelasyon Katsayıs1 & p \\
\hline Yüksek Düzey & 75,2 & 42,4 &,- 291 & \multirow{2}{*}{, 000} \\
\hline Düşük Düzey & 24,8 & 57,6 & \\
\hline
\end{tabular}

Tablo 8'de, ileri düzey finansal okuryazarlık seviyeleri ile bilişsel yetenek düzeyleri arasında zayıf da olsa bir ilişki vardır ve bu ilişki negatif yönlüdür. Bu durumun nedeni, yüksek bilişsel yetenek düzeylerindeki yatırımcıların \%75,2'si aynı zamanda ileri düzey finansal okuryazarlık yönünden de yüksek düzey grubunda yer alırken, düşük bilişsel yetenek düzeylerindeki yatırımcıların sadece \%42,4'ü ileri düzey finansal okuryazarlık yönünden yüksek düzey grubunda yer almaktadır. Buna karşın, yüksek bilişsel yetenek düzeylerindeki yatırımcıların sadece \%24,8'i ileri düzey finansal okuryazarlık yönünden düşük düzey grubunda yer alırken, düşük bilişsel yetenek düzeylerindeki yatırımcıların \%57,6'sı ileri düzey finansal okuryazarlık yönünden düşük düzey grubunda yer almaktadır. Sonuç itibariyle, yatırımcıların ileri düzey finansal okuryazarlık seviyeleri ile bilişsel yetenek düzeyleri arasında ilişki vardır $\left(\mathrm{H}_{1}\right)$ hipotezi kabul edilmektedir.

\section{SONUÇ VE ÖNERILER}

Davranışsal finans, psikoloji bilimi ile yatırımcı davranışlarını birbiri ile bağdaştırmayı içermektedir. Buna göre, bireyler (yatırımcılar) sistematik olarak psikolojik hatalara düşmekte ve bu hatalar bireylerin sağlıklı karar almasını engellemektedir. 
Eğitim düzeyinin yüksek olması, yatırım yapılan konularda farkındalık düzeyinin de yüksek olması algısını beraberinde getirmektedir. Ancak, araştırmadan elde edilen bulgulara göre, yatırımcıların eğitim düzeyleri ile finansal okuryazarlık düzeyleri aynı paralelde gözükmemektedir. Buna göre, katılımcıların yaklaşık \%87'si bir yükseköğretim programından mezun olmasına karşın, finansal okuryazarlık seviyeleri oldukça düşük düzeydedir.

Diğer taraftan, çalışma kapsamındaki yatırımcıların bilişsel yeteneği oldukça düşük düzeydedir. Bilişsel yetenek yönünden, yüksek düzeyde yer alan bireylerin Almanya'da \%48 ve Amerika'da \%40 olduğu düşünüldüğünde, bu çalışmada yatırımcılar için elde edilen yaklaşık \%27 oranı düşük kalmaktadır. Bunun yanında, Frederick'in (2005) çalışmasına paralel olarak elde edilen sonuçlar, erkeklerin kadınlara göre bilişsel yeteneklerinin daha yüksek olduğunu, genel olarak lisans ve lisansüstü mezunlarının yüksek düzey grubunu oluşturduğunu, genç ve orta yaş diye tarif edebileceğimiz 20-49 yaş grubundaki yatırımcıların yüksek bilişsel yetenek grubunda yer aldığını göstermektedir.

Davranışsal finans alanında yapılan çeşitli çalışmalarda, bireylerin sistematik bir şekilde psikolojik yanılsamalara düştüğü saptanmıştır. Bu çalışma içeresinde yer alan Türkiye'deki yatırımcılar da, psikolojik yanılsamalara oldukça yüksek oranlarda düşmektedirler. Örneğin, finansal piyasalarda alım satım yapan yatırımcıların birçoğu, yatırım kararlarını alırken geçmişteki fiyatlara göre karar verdiğini ifade etmektedir. $\mathrm{Bu}$ veri, çıpalama kısayolunun Türk yatırımcıları tarafından da kullanıldığını ve yatırımcıların teknik analizi varlık ediniminde sıkça kullandığı anlamına gelmektedir. Buna ek olarak, araştırma kapsamındaki yatırımcılarda yoğun bir şekilde aşinalık ve yerellik yanılsaması görülmekte, yatırımcılar mevcudiyet kısayolu kullanmakta ve yatkınlık etkisine maruz kalmaktadırlar. Öte yandan yatırımcılar, yatırım yaptıkları firmaya ilişkin olumsuz haberler veya firmanın başka bir firmayla birleşme haberleri ortaya çıktığında tutucu davranıp "eksik reaksiyon” vermekte, ancak firmanın yeni hisse senedi ihraç edeceğine ilişsin haberler ortaya çıktığında "aşırı reaksiyon” göstermektedirler.

Araştırma kapsamındaki erkek yatırımcılar, birleşme haberlerine aşırı tepki vermekte, aşinalık yanılsamasına düşmekte, yerellik yanılsamasına maruz kalmakta ve yatkınlık etkisine eğilimli olmaktadırlar. Yaş grupları açısından bakıldığında, çalışma kapsamında 30-39 ve 4049 yaş gruplarındaki yatırımcılar birleşme haberlerine aşırı tepki vermekte, başta 40-49 yaş grubu olmak üzere 20-29 ve 30-39 yaş grubundaki yatırımcılar kumarbaz yanılgısına en çok düşen yatırımcılar olmaktadır. Bunun yanında, 20-29 yaş grubundaki yatırımcılar, yerellik yanılsamasının en çok görüldüğü yaş grubu iken, 20-29 ve 30-39 yaş grubundakiler mevcudiyet kısayolunu en çok kullanan yaş grubudur. Son olarak, yatkınlık etkisi 20-29 yaş grubundakilerde oldukça fazla görülürken, 30-39 ve 40-49 yaş grubundakiler kısmen de olsa yatkınlık etkisine maruz kalmaktadır. Yatırımcılar eğitim düzeyleri bakımından incelendiğinde, lisans mezunları çıpalama kısayolunu en çok kullanan ve ihraç haberleri nedeniyle oluşan aşırı tepki yanılsamasına en çok maruz kalan yatırımcı grubudur. Ayrıca, 
lisans ve lisansüstü mezunları aşinalık yanılsamasının en çok görüldüğü eğitim düzeyleri iken, yatkınlık etkisine en çok maruz kalan eğitim düzeyleri ise, lisans ve önlisans mezunları olarak ortaya çıkmıştır.

Çalışmanın önemli bulgularından bir tanesi, yatırımcıların bilişsel yetenek düzeyleri yükseldiğinde, önyargılar konusunda farkındalık düzeyinin de kısmi olarak yükselme eğilimi gösterdiğidir. Özellikle, ihraç haberine karşı oluşabilecek aşırı tepki, yerellik yanılsaması ve mevcudiyet kısayolu konusunda bilişsel yeteneği yüksek olan yatırımcılar, bilişsel yeteneği düşük yatırımcılara göre daha duyarlı gözükmektedir. Bu durum, analitik düşünmenin olumlu bir katkısı olarak görülebilir.

Diğer taraftan, gerek temel finansal okuryazarlık gerekse de ileri düzey finansal okuryazarlık düzeyinin yüksek veya düşük olması önyargılara düşme konusunda etkili olmamaktadır. Bir başka anlatımla, yatırımcılarda psikolojik yanılsamalara düşmesi finansal okuryazarlık düzeyinden bağımsızdır. Ancak, bilişsel yetenek düzeyleri ile finansal okuryazarlık düzeylerine bakıldığında, bilişsel yeteneği yüksek olan yatırımcılar aynı zamanda, finansal okuryazarlık yönünden yüksek düzeydedir. Dolayısıyla, analitik düşünmenin önemi burada bir kez daha ortaya çıkmaktadır.

Özetle söylemek gerekirse, çalışma kapsamındaki yatırımcıların bilişsel yetenek ve finansal okuryazarlık düzeyleri Amerika, Almanya ve Hollanda'daki araştırmalar ile karşılaştırıldığında oldukça düşük düzeydedir. Benzer şekilde bu kapsamdaki yatırımcılar, yoğun bir şekilde psikolojik yanılsamalara maruz kalmaktadır.

Bu sonuçlardan yola çıkarak, yatırımcı davranışlarının daha etkin hale gelebilmesi için yapılması gerekenler aşağıda maddeler halinde sıralanmıştır;

Türkiye'deki yatırımcılar cinsiyetlerine göre değerlendirildiğinde, kadınların piyasa katılımı oldukça düşük düzeydedir. Türkiye'deki nüfusun cinsiyetlere göre dağılımının yaklaşık olarak eşit olduğu düşünüldüğünde, yatırımcıların sadece \%23'ünün kadınlardan oluşması sermaye piyasasının derinliği ve verimliliği açısından bir sorun teşkil etmektedir. Dolayısıyla, politika yapıcıların bu durumu dikkate alıp, yönlendirmeleri bu doğrultuda yapmaları gerekmektedir.

Türkiye'deki yatırımcıların bilişsel yetenek düzeyleri gelişmiş ülkelere göre oldukça düşük düzeydedir. Böyle bir durum, politika yapıcıların hedeflerinden bir tanesinin özelde yatırımcılar genelde ise tüm hanehalkı için bilişsel yetenek düzeylerinin artırılması olması gerektiği anlamına gelmektedir. Yapılan çalışmalar, bireylerin verilecek eğitim ile bilişsel yetenek düzeylerinin \%25 ile \%50 arasında arttırılabileceğini göstermektedir. Dolayısıyla, bireylerin tekdüze eğitimden ziyade, kural temelli ve analitik düşünceyi öngören bir eğitim ile donatılması, bilişsel yeteneklerinin de yükselmesine katkıda bulunacaktır. Böyle bir durumda, finansal piyasada aktör olan veya gelecekte aktör olacak bireylerin, çok daha sağlıklı ve sonuca olumlu katkı sağlayacak kararlar alması olanaklıdır. 
Çalışmadan elde edilen sonuçlara göre, Türkiye'deki yatırımcıların finansal okuryazarlık düzeyleri diğer ülkeler ile karşılaştırıldığında oldukça düşük düzeydedir. Son dönemde, yatırımcıların finansal okuryazarlık düzeylerinin geliştirilmesine ilişkin yapılan çalışmalar, geç kalınmış olsa da umut vericidir. Ancak, yatırımcıların finansal okuryazarlık düzeylerinin nasıl geliştirileceğine ilişkin somut önerilerin ilgili kurumlar tarafından net olarak ortaya konmaması ve yatırımcıların finansal okuryazarlık düzeylerinin arttırılmasıyla her sorunun çözüleceği gibi bir algı yaratılması, ortaya çıkan diğer bir sorundur. Dolayısıyla, ilgili kurumların, finansal okuryazarlık düzeyinin geliştirilmesinin yatırımcı kararlarının etkinliğine katkı sağlayacak konulardan sadece bir tanesi olduğunu ve bunun dışında başka diğer soruların da var olduğunu görmeleri gerekmektedir.

$\mathrm{Bu}$ çalışma ile, yatırımcıların finansal okuryazarlık düzeylerinin psikolojik önyargılara düşme konusunu tek başına çözümleyemediğine ilişkin önemli bulgulara ulaşılmıştır. Dolayısıyla, çözüm üretilmesi gereken asıl sorun, finansal okuryazarlık yönünden ihmal edildiği söylenen yatırımcıların, finansal okuryazarlık düzeylerinin yükseltilmesinin yanı sıra, eş zamanlı olarak onları piyasalarda görülen psikolojik yanılsamalar konusunda da bilgilendirmektir.

$\mathrm{Bu}$ çalışmada ayrıca, bilişsel yetenekler ile finansal okuryazarlık düzeyleri arasındaki ilişki araştırılmış ve bu iki değişken arasında pozitif bir ilişkinin olduğu görülmüştür. $\mathrm{Bu}$ sonuç, ilgili kurumların, Türkiye'deki yatırımcıların finansal okuryazarlık düzeylerinin arttırılması için çaba göstermelerini ancak bunu yaparken bilişsel yeteneklerini geliştirmeyi de ihmal etmemeleri gerektiğini göstermektedir. Diğer taraftan, bilişsel yeteneklerin geliştirilmesi elbette sadece finans piyasalarını yöneten kurumların sorunu olmayıp, genel anlamda tüm eğitim sistemini ilgilendiren bir durumdur. Bu nedenle, finansal piyasaları yöneten kurumlar ile eğitim sistemini yöneten kurumların, koordineli bir şekilde çalışarak hem finansal okuryazarlık hem de bilişsel yetenek düzeylerinin daha ileri seviyelere taşınması için politikalar geliştirmesi gerektiği düşünülmektedir.

Son olarak, bu çalışmada Türkiye'deki yatırımcıların çoğunun, bilişsel yetenek ve finansal okuryazarlık düzeylerinden bağımsız olarak, psikolojik önyargılar konusunda aynı yönlü hareket ettiği bulgulanmıştır. Bu durum, yatırımcıların ortak bir düşünce tarafından yönlendirildiğinin diğer bir ifadesi anlamına gelmektedir. Bu ortak düşünce, teknik analizin dikte ettiği "her şey fiyatlara yansır" söylemidir. Dolayısıyla yatırımcılar, finansal okuryazarlık ve bilişsel yetenek düzeyleri ne olursa olsun, bu ortak düşünce etrafinda birlikte hareket etmekte, grafiklerin içinde boğulmakta ve paralize olmuş bir şekilde kararlar almaktadırlar. Sonuç itibariyle, yatırımcıların daha sağlıklı kararlar almasına yardımcı olabilmek için, bilişsel yetenek ve finansal okuryazarlık düzeylerinin yükseltilmesinin yanında, politika yapıcıların temel amaçlarından bir diğeri de, yatırımcıların piyasada varolan yöntemlerin eksiklikleri hakkında da bilgi sahibi olmalarını sağlamak olmalıdır. 


\section{KAYNAKLAR}

Abaan, Ernur Demir, (2002) "Fayda Teorisi ve Rasyonel Seçimler", Araştırma Genel Müdürlüğü, Tartışma Tebliğgi, No: 2002/3.

Benartzi, Shlomo - Thaler, Richard, (1995) "Myopic Loss Aversion and the Equity Premium Puzzle”, The Quarterly Journal of Economics, Vol.110, No.1, pp.73-92.

Benjamin, Daniel - Shapiro, Jesse, (2005) "Does Cognitive Ability Reduce Psychological Bias?” Russell Sage Foundation, www.russellsage.org/research/reports/boundedcognition (16.09.2011).

Bucher-Koenen, Tabea - Ziegelmeyer, Michael, (2011) "Who Lost the Most? Financial Literacy, Cognitive Abilities and the Financial Crisis”, European Central Bank: Conference on Household Finance and Consumption, Working Paper Series, no.1299.

Callebaut, Werner, (2007) “Herbert Simon’s Silent Revolution”, Biological Theory, Vol.2, No.1, pp.76-86.

Cascio, Elizabeth - Lewis, Ethan, (2006), "Schooling and the AFQT: Evidence from School Entry Laws”, Journal of Human Resources, Vol.XLI, No.2, pp.294-318.

Christelis, Dimitris - Japelli, Tullio - Padula, Mario, (2010) "Cognitive Abilities and Portfolio Choice," European Economic Review, Vol.54, No.1, pp.18-38.

Fiori, Stefano, (2005) “Simon’s Bounded Rationality. Origins and Use in Economic Theory” CESMEP Working Paper Series, No.09/2005.

Friedman, Milton, (1953) “The Methodology of Positive Economics”, Essays in Positive Economics, The University of Chicago Press, Chicago.

Frederick, Shane, (2005) “Cognitive Reflection and Decision Making”, Journal of Economic Perspectives, Vol.19, No.4, pp.25-42.

Gigerenzer, Gerd - Selten, Reinhard, (2002) “Bounded Rationality-The Adaptive Toolbox”, Dahlem Workshop Reports.

Guiso, Luigi - Japelli, Tullio, (2008) “Financial Literacy and Portfolio Diversification”, CSEF Working Papers Series, No.212.

Hogart, Jeanne - Beverly, Sondra - Hilgert, Marienne, (2003) "Patterns of Financial Behaviors :Implications for Community Educators and Policy Makers” Discussion Paper, http://www.federalreserve.gov/communityaffairs/national/ca_conf_suscommdev/pdf/h ogarthjeanne.pdf (03.04.2011).

Kahneman, Daniel - Tversky, Amos, (1979) "Prospect Theory: An Analysis of Decision Under Risk”, Econometrica, Vol.47, No.2, pp.263-91.

Kimball, Miles - Shumway, Tyler, (2006), "Investor Sophistication and the Participation, Home Bias, Diversification, and Employer Stock Puzzles”, http://wwwpersonal.umich.edu/ mkimball/keio/z-Osaka-2007-after/sophist1.pdf ( 01.03.2012). 
Klapper, Leora - Lusardi, Annamaria - Panos, Georgios, (2012) "Financial Literacy and Financial Crisis”, Netspar Discussion Papers, No.DP 03/2012-007.

Lusardi, Annamaria - Tufano, Peter, (2009) "Debt Literacy, Financial Experiences and Overindebtedness,” NBER Working Paper No.14808. http://www.nber.org/papers/w14808 (17.08.2012)

Lusardi, Annamaria - Mitchell, Olivia - Curto, Vilsa, (2010) "Financial Literacy among the Young”, The Journal of Consumer Affairs, Vol.44, No.2, pp.358-380.

Lusardi, Annamaria - Mitchell, Olivia - Curto, Vilsa, (2012) "Financial Sophistication in the Older Population”, NBER Working Paper No.17863, http://www.nber.org/papers/w17863, (17.08.2012).

Nunnaly, Jum, (1978) "Psychometric Theory”, McGraw-Hill, New York.

Oechssler, Joerg - Roider, Andreas - Schmitz, Patrick, (2008) “Cognitive Abilities and Behavioral Biases”, University of Heidelberg Discussion Paper Series, No.465. http://www.uni-heidelberg.de/md/awi/forschung/dp465.pdf (11.07.2012).

Ritter, Jay, (2003) “Behavioral Finance”, Pacific-Basin Finance Journal, Vol.11, pp.429-437.

Simon, Herbert, (1956) "Rational Choice and the Structure of the Environment", Psychological Review, Vol.63, No.2, pp. 129-138.

Shefrin, Hersh, (2007) “Behavioural Corporate Finance”, McGraw-Hill, New York.

Thaler, Richard - Johnson, Eric, (1990) "Gambling with the House Money and Trying to Break Even: The Effects of Prior Outcomes on Risky Choice”, Management Science, Vol.36, No.6, pp.643-60.

TSPAKB, (2011) “Türkiye Sermaye Piyasası 2010:Sermaye Piyasasında GelişmelerYatırımc1 Analizi-Arac1 Kuruluşlar, http://www.tspakb.org.tr/tr/Portals/57ad7180c5e7-49f5-

b282c6475cdb7ee7/AIM_Yayin_ve_Raporlar_Yillik_Yayinlar_2010_yatirimcianalizi 2009.

Tversky, Amos - Kahneman, Daniel, (1974) “Judgment under Uncertainty: Heuristics and Biases”, Science, New Series, Vol.185, No.4157, pp.1124-1131.

Van Rooij, Maarten - Lusardi, Annamaria - Alessie, Rob, (2011) "Financial Literacy and Stock Market Participation”, Journal of Financial Economics, Vol.101, pp.449-472.

Zielonka, Piotr, (2004) "Technical Analysis as the Representation of Typical Cognitive Biases”, International Review of Financial Analysis, Vol.13, No.2, pp.217-225. 